\title{
A HAZAI SÜTŐIPAR HELYZETE NAPJAINKBAN
}

\author{
Szabó P. Balázs
}

\begin{abstract}
Absztrakt: A hazai sütőipari ágazatot számos probléma sújtja. Csökken a szakképzett munkaerő létszáma, a fiatalok nem választják a pék szakmát, valamint nagyon gyakori az elvándorlás is. Az átlagos bérszínvonal az élelmiszeripari ágazatok között a sütöiparban a legalacsonyabb, így a versenyszféra más területeihez képest még nagyobb a lemaradás. Ezekhez hozzájön még a sütőipari termékek magas ÁFA-ja is. Ebben a helyzetben kell a mai magyar tulajdonosi háttérrel rendelkező pékségeknek talpon maradni.
\end{abstract}

Abstract: The Hungarian bakery industry is affected by a number of problems. The number of skilled workers is decreasing, young people do not choose the baker's profession, and migration is very common. The average wage level among the food industry is the lowest in the baking industry, so there is a greater lag behind the other sectors of the business sector. In addition, high VAT on bakery products is also included. In this situation, the Hungarian ownership bakeries should remain on their feet.

Kulcsszavak: munkaeröhiány, jövedelmezőség, külföldi pékségek

Keywords: labour shortage, profitability, foreign bakeries

\section{Bevezetés - a sütőipar története}

A sütőipar a 14. századtól kezdődően a nagyobb városokban, ipari és a bányaközpontokban alakult ki. Egészen a 19. századig nagyon változatos volt, céhekbe tömörültek. Ez idötáj két csoportra oszlottak: a fehérpékekre (fehér kenyér, kifli, zsemle, finomsütemény, cukrásztermék) és a feketepékekre (házi kenyér, paraszt kenyér, barna kenyér, kalács, burgonyás kenyér). Ezen termékeket közvetlen fütésü kemencékben sütötték, melyeket legtöbbször fával fütöttek. Méretüket tekintve $6-8 \mathrm{~m}^{2}$ alapterületüek voltak. A tésztát fateknőben, kádakban készítették. Már ekkor jól felszereltek voltak eszközökkel (formák, mérleg, tálak stb.) ezek az üzemek, de a munka manuális volt. Az itt dolgozók folyamatosan, napi 14-20 órán át dolgoztak. 1872-ben eltörölték a céheket és rá egy évre megalakult a Budapesti Sütők Ipartársulata. Az ipartörvény (1884) ipartestületek alapítását írta elő, ennek következtében megalakult a budapesti sütö-, cukrász-, és mézeskalácsipar tagjainak közös ipartestülete. 1906-ban a cukrászok és a mézeskalácsosok kiváltak és létrejött a Budapesti Sütők Ipartestülete. Megjelentek a gépek is az iparban, darálók, dagasztógépek, a gőzkemence elődje. A sütőüzemek száma fokozatosan növekedett, Korona Kenyérgyár, Monori Kenyérgyár Rt. stb. sajnos ezek az üzemek nem igazán feleletek meg a közegészségügyi elöírásoknak. A 20. század elején lévő gazdasági válság a sütőipart is érintette. A lisztárak emelkedése magával vitte a kenyér árának emelkedését, így a kisebb cégek tönkrementek. Az 1990-ben kezdődő privatizáció hatására állami kézből gazdasági társaságokhoz kerültek a sütőipar létesítmények. A privatizáció mellett az új sütőipari vállalkozások, üzemek száma is növekedett, melyek föleg kis üzemek lettek, a települések helyi igényeinek kielégítését célozták meg. A 90-es évek közepétől megjelentek hazánkban a külföldi tulajdonú kiskereskedelmi áruházláncok is, amelyek áruházon belüli saját pékséggel 
rendelkeznek. Szintén a 90-es években létesültek olyan sütóipari vállalkozások, amelyek napjainkban már országosan franchise rendszerben értékesítik termékeiket. Ezek a vállalkozások fagyasztott pékáruk gyártásával és az üzletekben történő készre sütésével foglalkoznak. Ezekben az üzemekben a legmodernebb, teljesen automatizált gyártósorok találhatóak meg, minimálisra csökkentve az emberi erőforrás igényt. Természetesen a gyorsfagyasztásos technológiát, látva annak előnyeit a hagyományos előállításhoz képest, a kisüzemek is folyamatosan elkezdték bevezetni termelésükbe.

\section{A mai sütőipar helyzete hazánkban}

A Magyar Pékszövetség és a Központi Statisztikai Hivatal (2015) adatai alapján a sütöipari vállalkozások száma csökkenő tendenciát mutatott a 2000-es évek elejétöl 2011-ig, (1995-ben $1521 \mathrm{db}$, míg 2011-ben $1042 \mathrm{db}$ ), viszont 2012 óta minimális emelkedés látszódik (2014-ben 1096 db). 2009-es adatok alapján jól látható, hogy a sütőipari termékek értékesítésének több mint felét a multinacionális kereskedelmi láncok adják, és csak körülbelül $35 \%$ a kiskereskedelem és a saját szaküzlet által összesen értékesített mennyiség. Ennek megfelelöen napjainkban nagyon nehéz helyzetben vannak a sütőipari kis- és középvállalkozások. A kereskedelmi láncok lefelé nyomják az árakat, miközben emelkednek az előállítási költségek, és csökken a jövedelmezőségi mutató. A nagy élelmiszerláncok belépésével (saját pékségek) a piacra az árversenyben a kis pékségek eleve hátrányban vannak, mert a sütőipari termékeket vevőcsalogatónak használják, az előállítási ár alatt kínálják őket. A jövedelmezőségi mutató (az árbevétel és a profit alapján), míg 1992-ben 5,34\%, addig 2000-ben 2,46\%, 2013-ban pedig már csak 1\%. Mindezt tetőzi, hogy az utóbbi tíz évben jelentősen nőttek az alapanyagárak, a munkaerő és egyéb járulékos költségek. A fogyasztási kedv is csökken. A Központi Statisztikai Hivatal adatai szerint sokkal kevesebb kenyeret eszünk, mint korábban. Míg 2002-ben személyenként 62,7 kilogramm volt az éves fogyasztás, a legfrissebb adat már csak 38 kilogramm volt. A még mindig kedvelt és keresett fehérkenyér fogyasztás is jelentösen csökkent. A fehér kenyeret naponta vagy hetente többször fogyasztók aránya az elmúlt egy évtizedben $15 \%$-ot csökkent. Viszont a rozskenyérböl 66\%-kal, míg a teljes kiőrlésủ kenyerekböl 94\%-kal vásárolnak többet az elmúlt évtizedben a fogyasztók.

A pékségek számának 90\%-a kevesebb, mint 20 föt foglalkoztat. Viszont a magyarországi össztermelés 80\%-át adják, a maradék 10\%-ot közép és nagy vállalkozások adják. A szektor koncentrálódik a multik és a nagy üzemek kezében. Az előállított termékeket megközelítőleg 24,000 értékesítési ponton vehetik meg a vásárlók. Több mint felét multinacionális kereskedelmi láncokban; 15\%-át a pékségek saját mintaboltjaikban; a maradék egyharmad pedig kis kereskedelmi láncokban, közétkeztetésben és büfékben kerül eladásra. A hazai szakâgazat 2016os évi össztermelésének értéke megközelítőleg bruttó 156 milliárd forint. A foglalkoztatottak száma 20 ezerre tehető. 


\section{Problémák a sütőiparban}

Ma a magyar sütöipari vállalkozásokat számos tényező veszélyezteti. A multinacionális vállalatok a sütőipari termékeiket, előállítási vagy az alatti áron értékesítik (a kieső bevételt keresztfinanszírozással pótolják). Napjainkban hatalmas problémát jelent a munkaeröhiány, a cégek termelése került már veszélybe. Problémát jelent az utóbbi időben megszaporodott főleg albán (de szerb, horvát) pékségek száma.

\subsection{Munkaerőhiány a sütőiparban}

A tavalyi adatok szerint a pék szakma jelenleg a hiányszakmák 3. helyén áll, körülbelül 3000 állás betöltetlen. Jelenleg egyébként mintegy 20000 föt foglalkoztat az iparág. A munkaerőhiány két dologra vezethető vissza az egyik az alacsony bérszínvonal (átlagosan 150-160 000 Ft), a másik, hogy manapság sem a fiatalok, sem az átképzésen résztvevő felnőttek nem tartják vonzónak a pék szakmát. 2016ban a Magyar Pékszövetség elnöke Septe József Úr levelet írt a Nemzeti Agrárgazdasági Kamara (NAK) Élelmiszeriparért felelös elnökének Édes Tamásnak a helyzetröl. A NAK részéröl kezdeményezések indulnak különböző ösztöndíjjak, támogatások kidolgozására.

\subsection{Alacsony jövedelmezöség}

Az üzemek bevétele $0-3 \%$ között mozog. Ez nem elég semmire sem, sem béremelésre, se új gépek vásárlására, sem semmilyen fejlesztésre. Növelni sajnos a termékek árát csak nagyon nehezen lehet, pedig számítások szerint legalább 30\%-os termék árdrágulásra lenne szükség. Ennek oka föleg a fogyasztói árérzékenységben keresendö. Ez a mérték tudná fedezni többek között a dolgozó bérének emelését, amiröl a 3.1. pontban már irtunk. A Magyar Pékszövetség régóta kezdeményezi a sütőipari termékek, mint alapvető élelmiszerek áfájának 18\%-ról 5\%-ra történő mérséklését. 2016-ban a Magyar Pékszövetség elnöke Septe József Úr levelet írt Dr. Fazekas Sándor miniszter úr részére az áfa csökkentés szükségességéről. Erre a Kormánytól kapott ígéret szerint 2018-tól lenne lehetőség (Vöő, 2016).

\subsection{Külföldi pékségek - Albán pékségek}

A hazai sütödék száma folyamatosan csökken, a külföldieké folyamatosan nő és ez a tendencia folyamatos. Ma kb. 1100 magyar tulajdonú pékség müködik és 5-700 külföldi tulajdonú. A hazai vásárlók sajnos nagyon sokszor nincsenek tisztába, hogy magyar vagy külföldi tulajdonú pékségben vásárolnak-e. Sajnos e külföldi tulajdonú cégek közül sokan nem tartják be még az alapvetö jogszabályokat, élelmiszerhigiéniai elöírásokat sem. Termékeiket nem a Magyar Élelmiszerkönyv szerint készítik el. Nem csak az élelmiszertörvényeket nem tartják be, de az adó- és munkatörvényeket sem. Munkaidő nyilvántartást nem vezettek, bérpótlékot nem fizetnek, pihenőidőt nem adnak. A magyar hatóságoktól nem tartanak, mert elérhetőségnek külföldi címeket adnak meg, amelyek sokszor nem is valósak. Hiába veszik el egy cég adószámát, mert nem felelt meg az elöírásoknak, alapítanak egy másik vállalkozást. Ha az ügyvezetőt tiltják el, akkor más rokon fogja vinni a boltot. 
(Élő, 2013). Általában a vizsgált albán cégek mintegy 90\%-ánál találnak valamilyen szabálytalanságot a hatóságok (jogsértés, szabálytalan foglalkoztatás). Mégis ezek a cégek müködnek, a bolt mögött lévő kis üzemben készítik a terméket, aminek illata így becsalogatja a vásárlókat. A magyar tulajdonosi háttérrel rendelkező cégek, meg sokszor kis boltokba, üzletekbe szállítanak, ahova a termék már kihülve érkezik, így a friss termékből adódó előnyt is elvesztik a hazai cégek. Hasonló módon működnek a horvát és szerb pékségek is, számuk 50-60-ra becsülhető. Természetesen itt is, mint az albánoknál vannak kivételek, akik a hazai jogszabályi környezetet, elöírásokat betartva tisztességesen müködnek. A pékszövetség, annak érdekében, hogy a vásárló, a fogyasztó tudja, hogy magyar terméket vesz, bevezették a Magyar Pékáru Védjegyet a magyar sütőipari termékekre, aminek képe az 1. ábrán látható.

\section{1. ábra: Magyar Pékáru Védjegy}

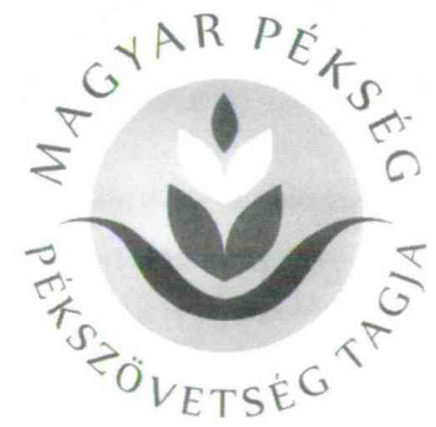

Forrás: http://www.pekszovetseg.hu/ (2017)

Ezt a védjegyet azokra a termékekre lehet használni, amelyek igazolhatóan magyar üzemben készültek, magyar alapanyagokból, magyar munkaerővel, ami minőségi garanciát jelent a fogyasztóknak.

\subsection{Fejlesztések}

A fejlesztések hiánya szintén nagy probléma, pedig a fejlesztések egyik nagyon fontos iránya a mélyhütött termékek gyártása. Ennek előnye, hogy az üzemben a teljes választék folyamatosan rendelkezésre áll (a mélyhütő, mint egy puffer müködik), a nappali mủszakok jobban kihasználhatóvá válnak (esetlegesen nem is lesz szükség éjszakai mủszakra), kisebb helyen, kisebb kapacitással, és csökkenő anyagfelhasználással megoldható ugyanaz a termelés, valamint a termék frissessége is javul (Werli, 2011). Természetesen ezt csak nagyfokú odafigyeléssel, a hütőben lévő termékek típusáról és mennyiségéről pontos nyilvántartást kell vezetni. Ezek a termékek vagy kelesztés nélküli gyorsfagyasztott termékek, vagy kelesztés utáni gyorsfagyasztott termékek, vagy elő (vagy készre) sütött termékek (Szilágyi, 2017). 


\section{Kitörési pontok}

Kitörési pont lehet a termékskála bővítése (lásd később 5. pont), a minőségi termékekre való átállás, valamint a franchise-rendszerü terjeszkedés. Ebben próbálnak meg segíteni a különböző pályázati támogatások. Az Európai Unió majdnem 300 milliárd forintos pályázati forrást nyit meg 2020-ig a kis és közepes élelmiszer-feldolgozó vállalkozások fejlesztésére. A Földmủvelésügyi Minisztérium közleménye szerint a jobb minőségü alapanyagokból készített, hagyományőrző pékáruk és az újfajta, egészséges péksütemények iránt egyre élénkül a vásárlói érdeklődés, ezért elengedhetetlen a gyártási technológia korszerüsítése és gazdaságosabbá tétele. A fogyasztók minőségre való igényét támasztja alá egy általunk végzett 2016-os felmérés is. 116 föt kérdeztünk meg, hogy feltérképezzük a sütőipari termékek fogyasztási szokásait. Az eredményből tisztán látszik, hogy a fogyasztók keresik a minőségi termékeket (2. ábra).

\section{2. ábra: Vásárlási szokások a minőség és az ár tekintetében}

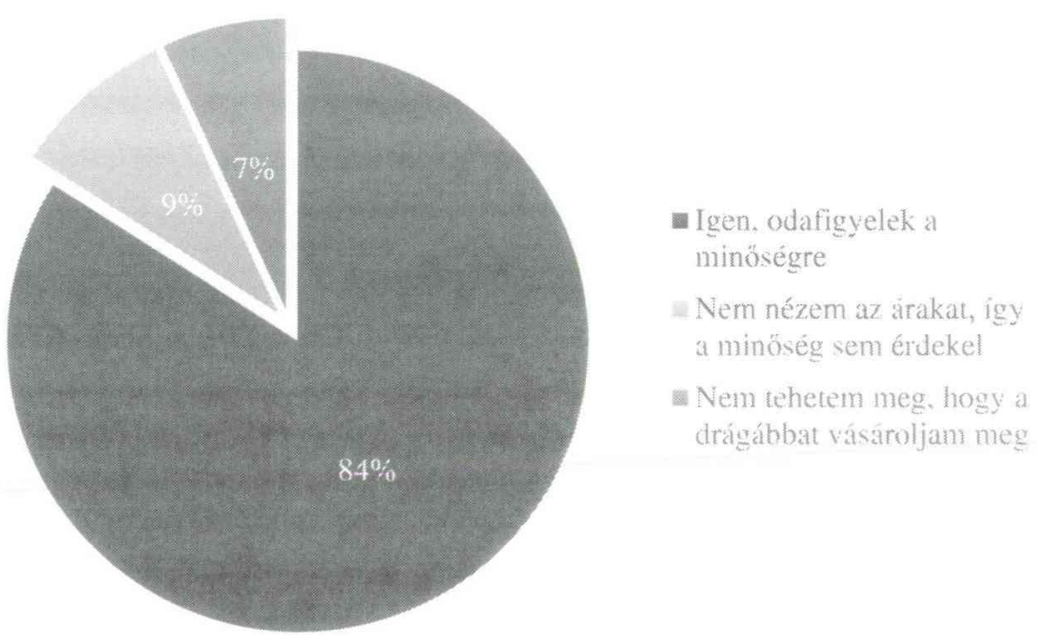

Forrás: Saját szerkesztés

A szakma bízik a viszonylag kedvezően elérhető vállalkozói hitelekben, illetve az európai uniós pályázatokban. Remélik, hogy ezek ösztönzően hatnak a jövőben, valamint az egyre korszerübb, az egészséges táplálkozást elösegítő, versenyképes élelmiszerek előállítása, stabilizálja az ágazat piaci helyzetét.

Napjainkban divatba jöttek a „mentes” élelmiszerek, ezt a sütőiparnak is követni kell. Ezek lehetnek a mindenféle mesterséges anyagoktól, E számoktól, stb. mentes termékek. Olyan termékek, melyek különleges táplálkozási igényeket is kielégítenek, funkcionális termékek. A sütőiparban megjelentek már, főleg a Nyugat-Európai országokban olyan trendek, hogy ökotudatos, különleges formák, snack termékek, ezeket lassan a tudatos hazai fogyasztók is keresni kezdik, ezért fel kell rá készülni (Flórián, 2016). 


\section{A sütőiparban megjelenő táplálkozási trendek}

Az utóbbi években az emberek étkezési szokásai átalakultak, ez főleg a mindennapi élet és a munka gyorsulása miatt, valamint az egyre egészségesebb ételek iránti kereslet miatt alakul így. A sütőiparnak is követni kell ezeket a változásokat. Egyik legjobb példa erre, hogy a kilósnál nagyobb kenyerek gyakorlatilag teljesen megszüntek, helyette a fél kilós, 300 g-os és 250 g-os termékek kezdenek teret szerezni maguknak, azaz a kisebb kenyerek felé megy el a piaci kereslet. Ennek oka az egyre több, kisebb (akár egyszemélyes) háztartásokra vezethető vissza, ahol is nincs szükség nagyobb mennyiségre. Megnőtt az igény a gyorsfagyasztott termékek iránt, mert ezeket helyben sütik készre és frissen melegen vásárolhatják meg a fogyasztók.

A vásárlók között egyre többen vannak, akik keresik az egészséges élelmiszereket, így az egészséges pékárukat is. Ezek a fogyasztók hajlandóak többet is fizetni ezekért a termékekért. Ilyenek egészséges termékek lehetnek a következők:

- Teljes kiőrlésü liszttel készült kenyerek, péksütemények

- Rozsos kenyér, rozskenyér

- Gluténmentes termékek

- Szénhidrát csökkentett termékek

- Allergén mentes termékek

- Természetes anyagokat tartalmazó termékek (mesterséges adalékoktól mentes)

- Vitaminnal és ásványi anyaggal dúsított termékek

- Rost dús termékek

- Magvakkal dúsított termékek

Ezekre a fejlesztésekre azért kell nagy figyelmet fordítani, mert a tradicionális sütőipari termékekben megtalálható minden, amit nem javasolnak (fehér liszt, cukor, só, élesztő). Ennek kicsit ellentmond, hogy megjelentek mostanában az igények a régi ízek iránt is. Ez mindenképpen érdekes jelenség.

A GFK Hungária Piackutató Intézet által kiadott sajtóközleményben az egészségtudatosságra vonatkozó felmérés az mutatja, hogy 1999 ás 2016 között 52\%-ról 76\%-ra nött azok száma, akik figyelnek az általuk elfogyasztott ételekre, föleg azokra melyekkel elérhetik, vagy megtarthatják ideális testsúlyukat. Leírják a kenyérfogyasztás szokásainak megváltozását is, melyből kiderül, hogy a fehér kenyeret fogyasztók aránya a 2007. évi 76\%-ról 2016-ban 61\%-ra csökkent. Változtak a különbözỏ kenyértípusok iránti keresletek is, rozskenyérböl 66\%-al, teljes kiörlésü kenyérböl $94 \%$-al vásároltak többet a fogyasztók (http://www.gfk.com/, 2017).

\section{6. Összegzés}

Mi lehet akkor a megoldás. Kitörési pont lehet a saját bolthálózat nyitása. Ezekben bővített szolgáltatásokkal (kávé, szendvics, stb.), valamint az egészséges életmódhoz kapcsolódó termékek árusításával lehet vásárlókat nyerni. Nagy hangsúlyt kell fektetni a prémium minőségü és különleges termékek előállítására, árusítására. 
Az idei, 2017-es év, a minimálbér nagymértékủ növekedése magával hozza az árak emelkedését az iparágban. Ez körülbelül 30\%-os áremelést tenne indokolttá, viszont ez a valóságban 5-10\%-os emelést jelentett néhány vállalkozásnál. Sajnos sok gyártó a partnerekkel való tárgyalások után még ennyit sem tudott érvényesíteni. Ez az egyik legnagyobb probléma, az iparág gyenge ár-érdekérvényesítő képessége az élelmiszer-termékláncon belül. Ez esetben sajnos az eddigi kis haszon is eltünhet, amit vagy a termékeinek a minőségének a gyengülésével próbál kompenzálni a pék, vagy nem szállít tovább annak a partnernek, vagy sajnos a pékség csődjét jelentheti.

\section{Irodalomjegyzék}

Élö A.: Egy albán százat csinál <http://valasz.hu/itthon/egy-alban-szazat-csinal-70057> (2013.11.06.)

Flórián Zoltán (2016): Hova tovább sütỏipar, Pékmester, 26 (12): 16.

GFK Hungária Piackutató Intézet kutatásai (2017)

Nemzeti Agrárgazdasági Kamara: Lét és nemlét határán a sütöipar (2016.11.18.) <https://www.nak.hu/kamara/kamarai-hirek/orszagos-hirek/92762-let-es-nemlet-hataran-asutoipar>

Szilágyi P. (2017): A Magyar Pékszövetség programja a szakágazat fejlesztésére. Pékmester 27 (4): 28.

Vöö Gy.: Harmincszázalékos kenyérdrágulás várható januártól. magyarhírlap.hu <http://magyarhirlap.hu/cikk/71856/Harmincszazalekos_kenyerdragulas_varhato_januartol> (2016.11.18.)

Werli J.: Idó- és termelés hatékony technológiák <https://www.sutoipariegyesules.hu/index.php? option=com_content\&view=article\&id=446:id-es-termeles-hatekony-technologiak\&catid=15: szakmai-publikaciok\&Itemid $=53>(2011.03 .22$. $)$ 